\title{
Em memória de Cecil Helman
}

Francisco Arsego de Oliveira

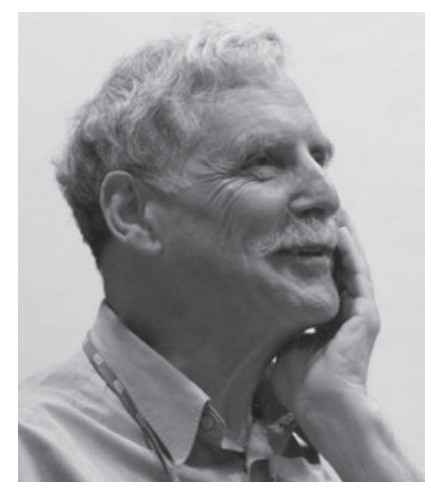

A Antropologia Médica e a Medicina de Família e Comunidade brasileiras perderam uma referência importante com o falecimento precoce de Cecil Helman, aos 65 anos de idade.

Nascido na África do Sul, no seio de uma família de médicos, formou-se em Medicina naquele país, migrando logo após para a Inglaterra, onde trabalhou como General Practitioner vinculado ao National Health Service (NHS) por quase 30 anos.

Desde cedo, interessou-se pela Antropologia Médica, vindo a realizar uma sólida formação acadêmica e assumindo uma posição de liderança mundial na área, sendo esse pioneirismo reconhecido por meio de importantes prêmios.

Helman era um apaixonado pelo Brasil e exerceu grande influência na Antropologia Médica brasileira, especialmente a partir do seu principal livro "Cultura, Saúde e Doença”, publicado em 1984 - a primeira edição brasileira foi publicada dez anos após. Com certeza, essa é a sua obra mais conhecida, com traduções em várias línguas e que chegou à sua $5^{a}$ edição brasileira em 2009. É nesse livro que o autor esmiúça a relação dos aspectos culturais com o processo saúde-doença, conceito fundamental para uma prática em saúde que se pretenda efetiva e culturalmente sensível.

Uma característica que marcou a sua carreira era a facilidade de transitar, como poucos, entre a antropologia médica e a prática médica em si, conseguindo estabelecer uma ligação entre esses dois campos do conhecimento e apontando, com clareza, a sua complementaridade. Isso explica como ele permaneceu militando de forma tão extraordinária nessas duas áreas por tanto tempo, colocando em prática o que ele próprio chamava de "antropologia médica clinicamente aplicada".

Essa característica ficou marcada também no seu livro, que buscava sempre explicitar essa relação por meio de inúmeros exemplos. Embora com conteúdo aprofundado, foi escrito de modo a propiciar uma leitura agradável, sendo adotado como referência bibliografia por inúmeros cursos teóricos e contribuído para tornar a Antropologia Médica mais acessível aos profissionais de saúde. Por outro lado, consegue igualmente mostrar a complexidade da prática em saúde também aos profissionais oriundos das Ciências Sociais.

Helman parecia não se acomodar. Cada edição do livro continha novos capítulos, indicando a necessidade de estar em sintonia com o que acontecia ao seu redor e com as mudanças constantes do mundo atual. Isso explica, por exemplo, a inclusão, na última edição, dos capítulos sobre migração, telemedicina e internet.

Helman esteve várias vezes no Brasil, país que admirava pela diversidade cultural e pelo rico trabalho desenvolvido pelos Médicos de Família e Comunidade junto à popu- 
lação. Participou de diversos eventos da nossa especialidade e desenvolveu projetos de pesquisa, tendo feito inúmeros amigos. Extremamente cordial e com uma voz mansa, sempre se mostrava curioso em ouvir a exuberância de aspectos culturais trazidos pelo público nas suas palestras.

O seu último livro, The Suburban Shaman (publicado em 2004 e sem tradução para o português) é um fantástico relato semibiográfico de casos atendidos por ele durante a sua trajetória profissional. Coerentemente com a ideia defendida por Helman, de que a "arte médica é uma arte literária", o livro reúne ótimos exemplos da essência da prática do médico de família, ou seja, conseguir estabelecer uma comunicação adequada com o paciente, simplesmente conseguir ouvi-lo em sua plenitude.

A sua obra evidencia, de modo contundente, que a compreensão da "narrativa" de cada ser humano sob os nossos cuidados é o que torna possível colocar-se na posição do paciente e entender a sua história, a sua cultura, os seus "personagens", o contexto em que estamos inseridos e o quanto esse conjunto é importante nas questões relacionadas à saúde e à doença. 